\title{
Past and current sediment dispersion pattern estimates through numerical modeling of wave climate: an example of the Holocene delta of the Doce River, Espírito Santo, Brazil
}

\author{
ABÍLIO C.S.P. BITTENCOURT ${ }^{1}$, JOSÉ M.L. DOMINGUEZ ${ }^{1}$, LOUIS MARTIN ${ }^{2}$, \\ IRACEMA R. SILVA ${ }^{3}$ and KARLA O.P. DE-MEDEIROS ${ }^{1}$ \\ ${ }^{1}$ Laboratório de Estudos Costeiros/CPGG, Instituto de Geociências/UFBa, Rua Barão de Geremoabo, s/n \\ Campus Universitário da Federação, 40170-290 Salvador, Bahia, Brasil \\ ${ }^{2}$ IRD(ORSTOM)/CNPq, Instituto de Geociências/UFBa, Rua Barão de Geremoabo, s/n \\ Campus Universitário da Federação, 40170-290 Salvador, Bahia, Brasil \\ ${ }^{3}$ Universidade Católica de Salvador, UCSAL/CEPEX, Av. Anita Garibaldi, 2981 \\ 41940-450 Salvador, Bahia, Brasil \\ Manuscript received on July 11, 2006; accepted for publication on October 31, 2006; \\ contributed by LOUIS MARTIN*
}

\begin{abstract}
This paper presents a numerical modeling estimation of the sediment dispersion patterns caused by waves inciding through four distinct coastline contours of the delta plain of the Doce River during the Late Holocene. For this, a wave climate model based on the construction of wave refraction diagrams, as a function of current boundary conditions, was defined and was assumed to be valid for the four coastlines. The numerical modeling was carried out on basis of the refraction diagrams, taking into account the angle of approximation and the wave height along the coastline. The results are shown to be comparable with existing data regarding the directions of net longshore drift of sediments estimated from the integration of sediment cores, interpretation of aerial photographs and $\mathrm{C}_{14}$ datings. This fact apparently suggests that, on average, current boundary conditions appear to have remained with the same general characteristics since $5600 \mathrm{cal}$ yr BP to the present. The used approach may prove useful to evaluate the sediment dispersion patterns during the Late Holocene in the Brazilian east-northeast coastal region.
\end{abstract}

Key words: Past and current sediment dispersion, wave refraction, numerical modeling, Holocene, Brazil.

\section{INTRODUCTION}

Based on a numerical modeling carried out using wave refraction diagrams, Bittencourt et al. (2005) present a sediment transport model that reproduces, on a regional scale, the sediment dispersion patterns along a coastal section approximately $3,000 \mathrm{~km}$ long in the east-northeast Brazilian region. These patterns were shown by the authors to correspond, on a large scale, to those proposed by Dominguez et al. (1992), based on paleogeographic reconstructions, as having persisted on the east-

\footnotetext{
*Member Academia Brasileira de Ciências

Correspondence to: Dr. A.C.S.P. Bittencourt

E-mail: abilio@pesquisador.cnpq.br
}

northeast Brazilian coast since the Late Quaternary. In general, such persistence seems to be basically related to the marked stability of the high pressure South Atlantic cell, which determines the trade winds system generated in it to be also markedly stable. This result in a great stability in the direction and velocity of these winds and, consequently, in dispersion of sediments along the eastnortheast Brazilian coast (Dominguez et al. 1992). Thus, the methodology and boundary conditions used by Bittencourt et al. (2005), seem to be adequate to reproduce past sediment dispersion patterns in the Brazilian eastnortheast region during the Late Quaternary, which will be evaluated in the present paper. 
The Quaternary plain of the Doce River mouth (Fig. 1), in the eastern Brazilian region, has been object of several studies (Bacoccoli 1971, Suguio and Martin 1981, Suguio et al. 1982, Dominguez 1987, Dominguez et al. 1981, 1987, Martin and Suguio 1992, Martin et al. 1997). A detailed map showing the various absolute datings (Suguio and Martin 1981, Suguio et al. 1982, Dominguez 1987, Dominguez et al. 1987), shows that the coastal plain was developed against Miocene deposits of the Barreiras Formation (Suguio and Nogueira 1999) where the following types of deposits can be distinguished (Fig. 1): a) Pleistocene marine terraces associated to the subsequent regression of a transgressive maximum dated 123,000 yr BP, and b) Holocene deposits associated to the subsequent regression of a transgressive maximum dated from 5600 cal yr BP, where lagoon and river deposits of an intra-lagoon delta, and two generations of sandy marine terraces can be identified. A diachronic vision of the coastline positioning during the Holocenic evolution of the coastal plain is also available, for which the directions of net longshore drift of sediments active in each period were reconstructed, based on the integration of sediment cores, interpretation of aerial photographs and $\mathrm{C}_{14}$ datings (Dominguez 1987, Dominguez and Wanless 1991, Dominguez et al. 1992, Martin and Suguio 1992, Martin et al. 1997). Along the current coastline, there are geomorphic indicators of the net longshore drift obtained from aerial photographs.

Regarding the Holocene evolution of the coastal plain, the deposition started with the formation of a barrier-island/lagoon system that reached its final position around approximately $5600 \mathrm{cal}$ yr BP. At that time, the barrier-island formed an ample bight on its north side, where the first generation of sandy terraces were deposited between approximately 5600 and $3800 \mathrm{cal}$ yr BP. After this, a second generation of marine terraces was deposited.

The objective of the present paper is to develop a simulation to verify the applicability of the method used by Bittencourt et al. (2005), as well as the current boundary conditions, in order to reproduce the sediment dispersion patterns defined along different positions of the coastline from the Holocene to the present, in the coastal plain associated with the Doce River mouth.

\section{PHYSIOGRAPHIC ASPECTS}

The coastal plain of the Doce River mouth has a length of $150 \mathrm{~km}$ and a maximum width of $40 \mathrm{~km}$ (Fig. 1). The Doce River has a $750 \mathrm{~km}$ course and a watershed basin of approximately $83,000 \mathrm{~km}^{2}$, located in a hot and humid tropical climate region with summer rains and a dry fall-winter season.

The continental shelf has a variable width, ranging from $50 \mathrm{~km}$ in the south to $220 \mathrm{~km}$ in the north, being relatively uniform in its southern half and irregular in the northern half. (Fig. 1).

\section{ATMOSPHERIC CIRCULATION SYSTEM}

The area under study is entirely located within the South Atlantic trade winds belt (NE-E-SE) that is related to the high-pressure cell, which exists in this region (Bigarella 1972, Martin et al. 1998). Another important atmospheric circulation element in this region is the periodic advance of the Atlantic Polar Front during the autumn and winter, generating SSE winds (Dominguez et al. 1992, Martin et al. 1998). It should also be noted that, on an inter-annual scale, the high-pressure cell normally shows a tendency to remain relatively stationary. Seasonally, however, this cell tends to expand and contract. In the coastal zone, this movement of the highpressure zone controls the position of the Divergence Zone (DZ) between the trade winds sensu-stricto (SE) and the return trade winds (NE). During the winter, the DZ is located at approximately $20^{\circ} \mathrm{S}$, while in the summer the position changes to approximately $13^{\circ} \mathrm{S}(\mathrm{Bi}-$ garella 1972, Dominguez et al. 1992, Martin et al. 1998).

\section{WAVE CLIMATE MODEL}

Significant direct measurements of the wave regime in the study area are not available. Wave statistics (height and period) used in this study were extracted from Hogben and Lumb (1967) (Area 37), which registered data obtained from visual observations taken on the open sea from ships. On the other hand, considering that along the east Brazilian coastal region, the sea-type waves are much more common than the swell-type waves (Davies 1972) - which is also confirmed by wave statistics given in Hogben and Lumb (1967) - local trade wind data were used to derive the frequencies regarding wave fronts 


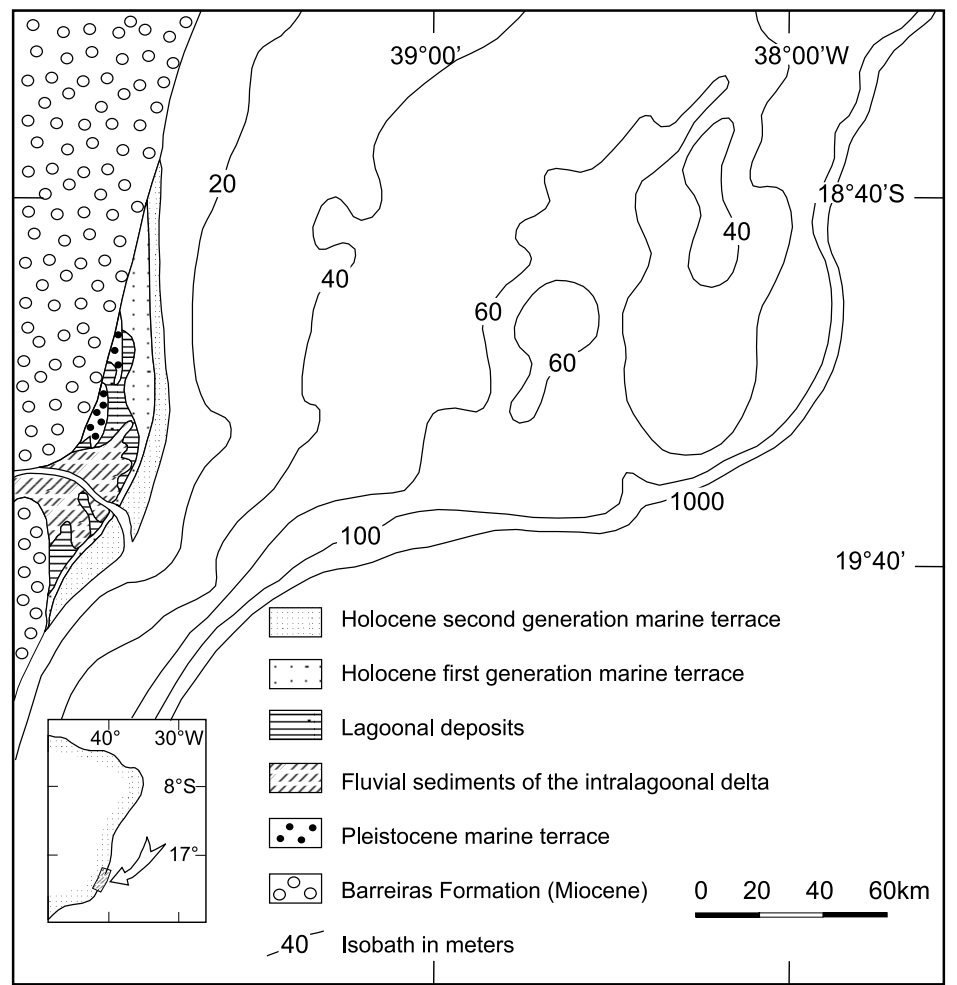

Fig. 1 - Schematic geological map of the coastal plain associated to Doce River mouth and morphology of the continental shelf.

reaching the coastline. Following are the average annual directions and frequencies of winds (the latter redimensioned to $100 \%$ ) (DHN 1993), regarding a time series from 1951 to 1972 , that can generate waves directed to the coastline: $\mathrm{NE}\left(\mathrm{N} 45^{\circ}\right)-39 \%, \mathrm{E}\left(\mathrm{N} 90^{\circ}\right)-$ $28 \%, \operatorname{SE}\left(\mathrm{N} 135^{\circ}\right)-18 \%$ and $\operatorname{SSE}\left(\mathrm{N} 157.5^{\circ}\right)-15 \%$. For these wave directions, the predominant periods and heights associated to them were considered to be, according to Hogben and Lumb (1967): period of $5 \mathrm{sec}$ and height of $1 \mathrm{~m}$ for $\mathrm{NE}$ and $\mathrm{E}$ waves and period of $6.5 \mathrm{sec}$ and height of $1.5 \mathrm{~m}$ for SE and SSE waves.

Based on these data, wave refraction diagrams were constructed manually, in accordance with the procedures described in CERC (1984), resulting in a generic wave climate model for the area under study. The bathymetric data used in the construction of these diagrams were extracted from a Brazilian Navy nautical chart on an approximate scale of 1:300,000. The waves were not propagated to water depths less than $10 \mathrm{~m}$, which is the closest limit to the coastline on the nautical chart. In addi- tion to the present coastline (Fig. 2), refraction diagrams were constructed for three other distinct Holocene scenarios for the coastline position described by Dominguez (1987) and Dominguez and Wanless (1991) (Fig. 3): a) around approximately $5600 \mathrm{cal}$ yr B.P., corresponding to the barrier-island coastline (Fig. 4), b) immediately after 5600 cal yr BP, corresponding to the coastline position during the deposition of the first generation of marine terraces (Fig. 5), and c) around approximately 3800 cal yr BP, corresponding to the coastline position after the end of the deposition of the first generation of marine terraces (Fig. 6). The current position of the coastline corresponds to the second generation of marine terraces, with the Doce River discharging into the ocean through a single channel (Fig. 2A). The refraction diagrams constructed based on current boundary conditions, had their wave-rays refracted to the 10 $\mathrm{m}$ isobath and, from there, the last propagation direction was maintained, extending to the coastlines mentioned above (Figs. 2B and $4 \mathrm{~B}$ to $6 \mathrm{~B}$ ). 


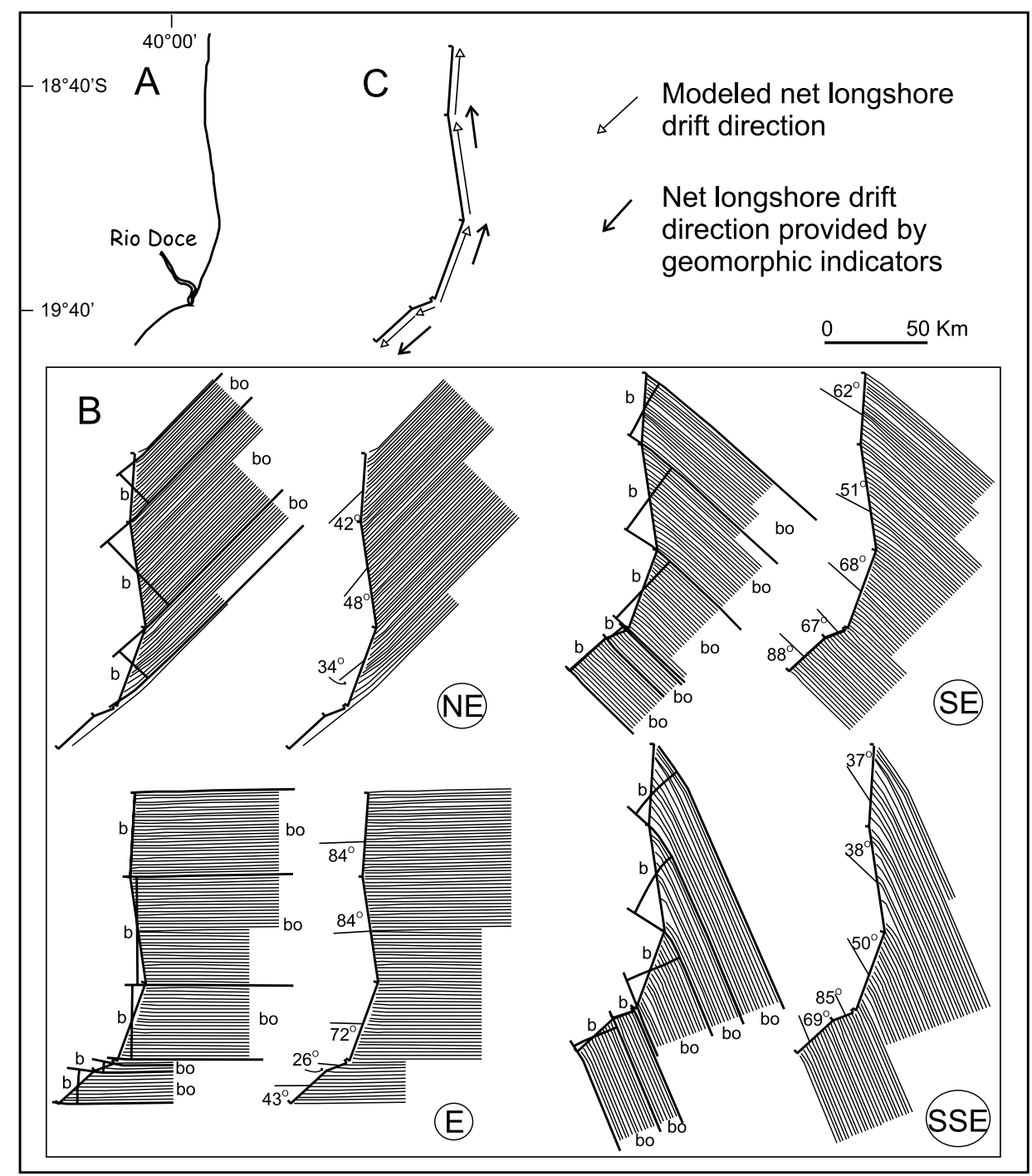

Fig. 2 - (A) Current coastline in the Doce River mouth. (B) Refraction diagrams for waves with a 5-s period, coming from NE and E, and 6,5-s period, coming from SE and SSE. Here are also shown: 1) different segments into which the shoreline was rectilinearized, 2) incidence angles formed by the wave-rays in relation to the coastal segments and 3) measurements of $b$ and $b_{o}$ (see text) used to estimate wave height along the shore segments. (C) Rectilinearized shoreline showing the directions of net longshore drift of sediments estimated from numerical modeling and from geomorphic indicators.

\section{DETERMINATION OF THE NET LONGSHORE DRIFT DIRECTION}

The direction of net longshore drift of sediments was determined by the calculation of potential intensity of longshore drift for each of the different wave-front directions, according to the method described in Bittencourt et al. (2005). Thus, the potential longshore drift intensity, for each wave-front was expressed by a nondimensional number, considering the function:

$$
x=\sin \alpha \cdot \cos \alpha \cdot H^{2},
$$

where $x$ is the longshore drift intensity, $\alpha$ is the incidence angle of the wave-front to the coastline, and $H$ is the normalized height of the wave (ie., the results were divided by a constant with the value of $1 \mathrm{~m}$ ). The height of the 


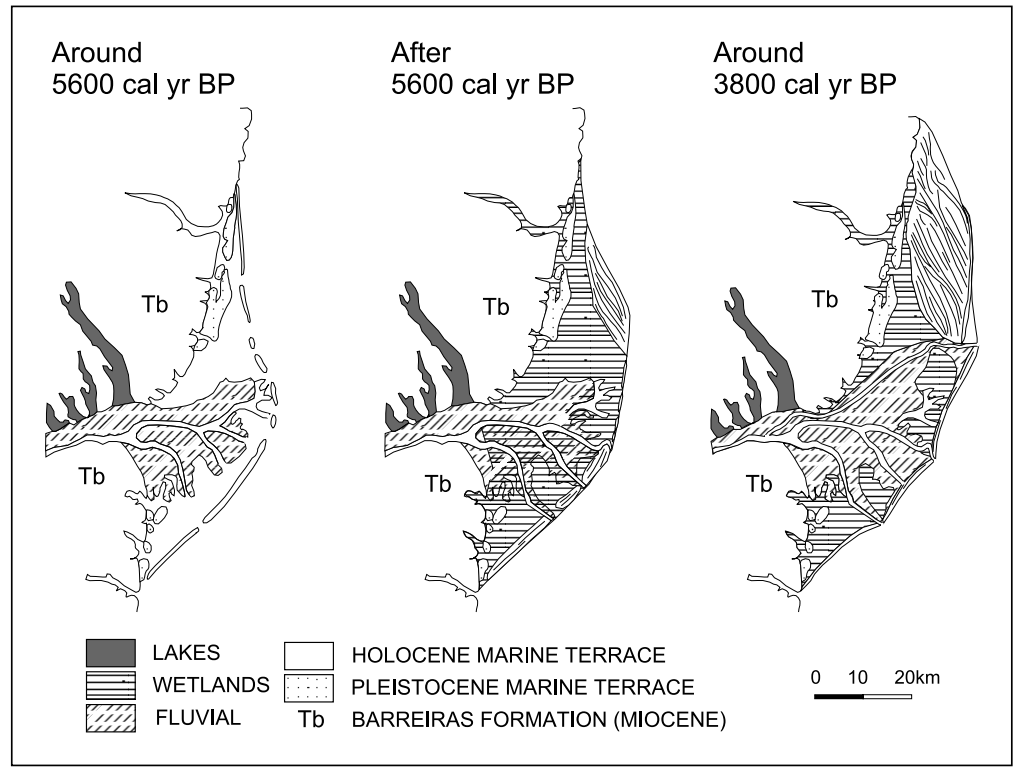

Fig. 3 - Paleogeographic maps of the coastal plain associated to Doce River mouth from 5600 to $3800 \mathrm{cal}$ yr BP. (according to data from Dominguez 1987, Dominguez and Wanless 1991).

wave along the coastline was estimated in accordance with the equation (Bascom 1954):

$$
H=H_{o}\left(\frac{b_{o}}{b}\right)^{1 / 2},
$$

where the subscript zero designates the conditions of deep waters and, $b$, the distance between adjacent sets of wave-front orthogonal. The coastline was divided into segments each of which approximated to a straight line, in accordance with the orientation of the coastline (Figs. $2 \mathrm{~B}$ and $4 \mathrm{~B}$ to $6 \mathrm{~B}$ ). Later, the value obtained for drift intensity was multiplied by the percentage of the annual frequency of wind direction to which the wave-front under consideration is associated. In the coastal sections presenting opposing drift directions during the year, the direction of net longshore drift was defined considering the predominant direction given by the difference of intensity between opposing drifts.

\section{RESULTS AND CONCLUSIONS}

Figures $2 \mathrm{C}$ and $4 \mathrm{C}$ to $6 \mathrm{C}$ present the directions of net longshore drift of sediments estimated in the present paper, as well as of those reconstructed by geological indicators, where it can be seen that they are comparable among themselves. Thus, it can be concluded that, in spite of the limitations inherent to the methodology used herein (see Bittencourt et al. 2005), in addition to the uncertainties regarding the boundary conditions and to the simplified suppositions incorporated in the model, the model showed its usefulness for reproducing past and current sediment dispersion patterns during the evolution of the coastal plain associated with the Doce River delta in the Late Holocene. This fact may mean that, on average, regarding the Brazilian east-northeast region, current wave conditions, as well as the morphology of the continental shelf, seem to have remained with the same characteristics from approximately $5600 \mathrm{cal}$ yr BP to the present time. However, in certain limited periods, for example, between 5600 and $3800 \mathrm{cal}$ yr BP, phases of localized erosion can be seen, testifying to modifications in the coastal dynamics. It seems that these erosions are a consequence of the existence of periods of some decades of years during which the waves from the SSE were weakened or absent (Martin and Suguio 1992). A time reconstruction of these anomalies may furnish valuable information concerning modifications in the characteristics of the atmospheric circulation with durations of several decades of years. This type of in- 


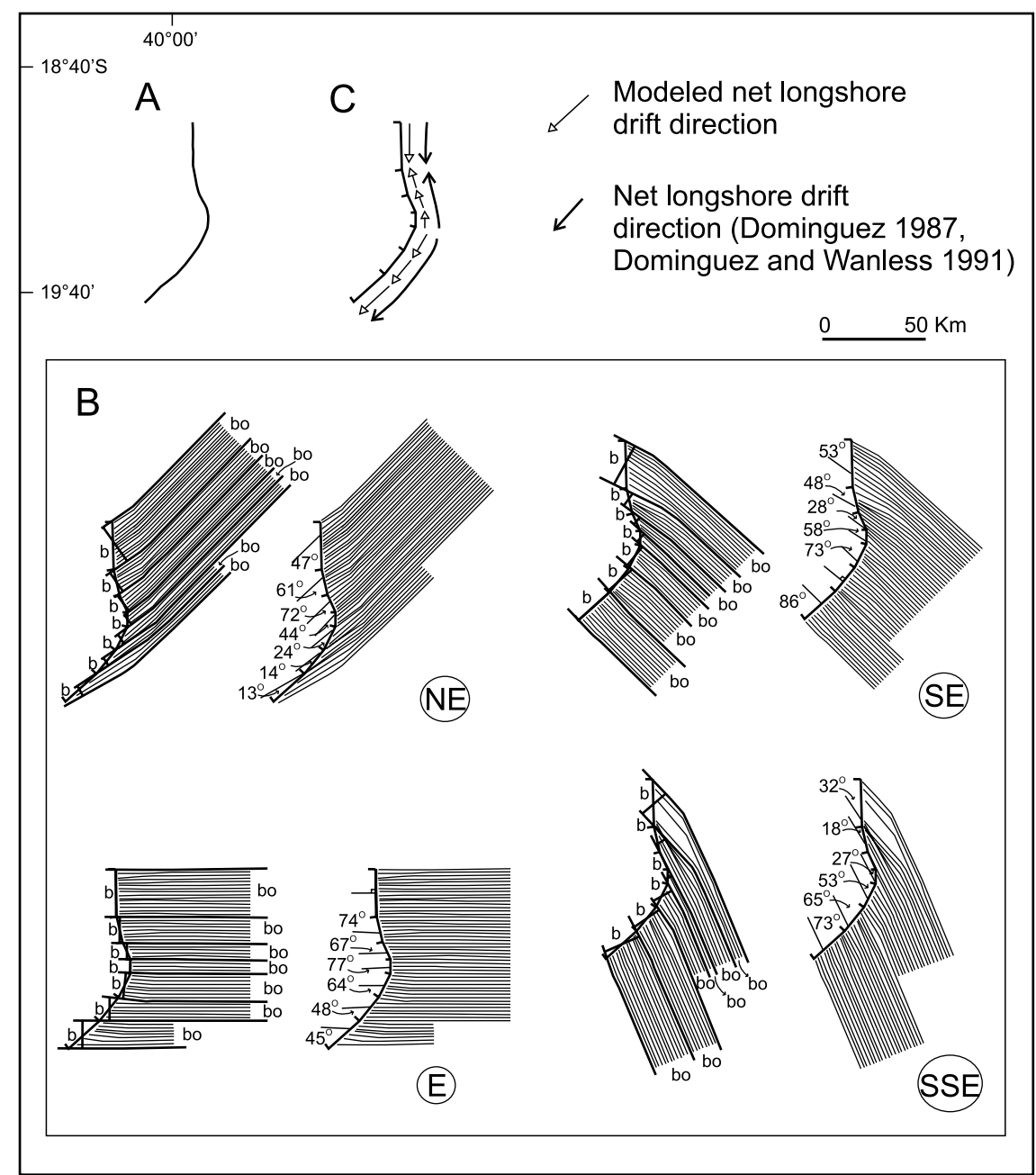

Fig. 4 - (A) Coastline in the Doce River around 5600 cal yr BP (see Fig. 3). (B) Refraction diagrams for waves with a 5-s period, coming from NE and E, and 6,5-s period, coming from SE and SSE. Here are also shown: 1) different segments into which the shoreline was rectilinearized, 2) incidence angles formed by the wave-rays in relation to the coastal segments and 3) measurements of $b$ and $b_{o}$ (see text) used to estimate wave height along the shore segments. (C) Rectilinearized shoreline showing the directions of net longshore drift of sediments estimated from numerical modeling and from Dominguez (1987) and Dominguez and Wanless (1991).

formation may be very important for the simulation of future situations.

\section{ACKNOWLEDGMENTS}

A.C.S.P. Bittencourt, J.M.L. Dominguez and K.L.P. de Medeiros thank Conselho Nacional de Desenvolvimento Científico e Tecnológico (CNPq), the first two for the Research Fellowship/Grant and the third for her Scientific Initiation Scholarship. The authors are in debt to two anonymous reviewers for their comments and suggestions.

\section{RESUMO}

O presente trabalho apresenta uma estimativa, por modelagem numérica, dos padrões de dispersão de sedimentos causados por ondas ao longo de quatro distintos traçados da linha de costa durante o Holoceno Tardio na planície deltaica do Rio Doce. Para tanto, foi definido um modelo de clima de on- 


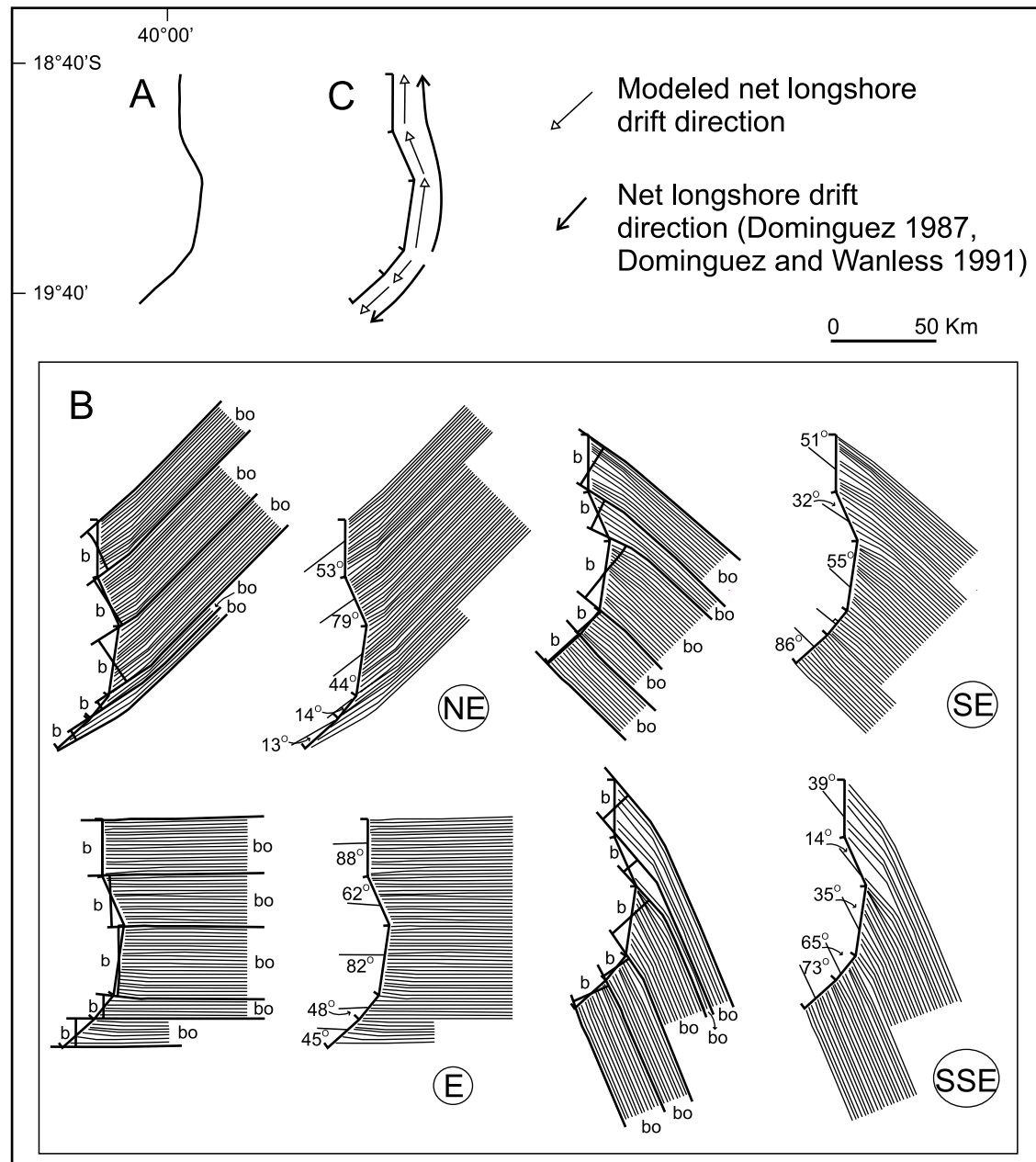

Fig. 5 - (A) Coastline in the Doce River immediately after 5600 cal yr BP (see Fig. 3). (B) Refraction diagrams for waves with a 5-s period, coming from NE and E, and 6,5-s period, coming from SE and SSE. Here are also shown: 1) different segments into which the shoreline was rectilinearized, 2) incidence angles formed by the wave-rays in relation to the coastal segments and 3) measurements of $b$ and $b_{o}$ (see text) used to estimate wave height along the shore segments. (C) Rectilinearized shoreline showing the directions of net longshore drift of sediments estimated from numerical modeling and from Dominguez (1987) and Dominguez and Wanless (1991).

das baseado na construção de diagramas de refração de ondas, em função das condições de contorno atuais, que foi assumido como válido para as quatro linhas de costa. A modelagem numérica foi realizada a partir dos diagramas de refração, levando-se em conta o ângulo de aproximação e a altura da onda ao longo da linha de costa. Os resultados obtidos mostraram-se compatíveis com os dados existentes relativos aos sentidos da deriva litorânea efetiva de sedimentos estima- dos a partir da integração de testemunhos de vibração, interpretação de fotos aéreas e datações por $\mathrm{C}_{14}$. Esse fato aparentemente sugere que, em média, as condições de contorno atuais parecem ter permanecido com as mesmas características gerais desde 5.600 cal yr BP até o atual, bem como que a abordagem aqui utilizada poderá ser útil para a avaliação de padrões de dispersão de sedimentos durante o Holoceno Tardio na região costeira leste-nordeste brasileira. 


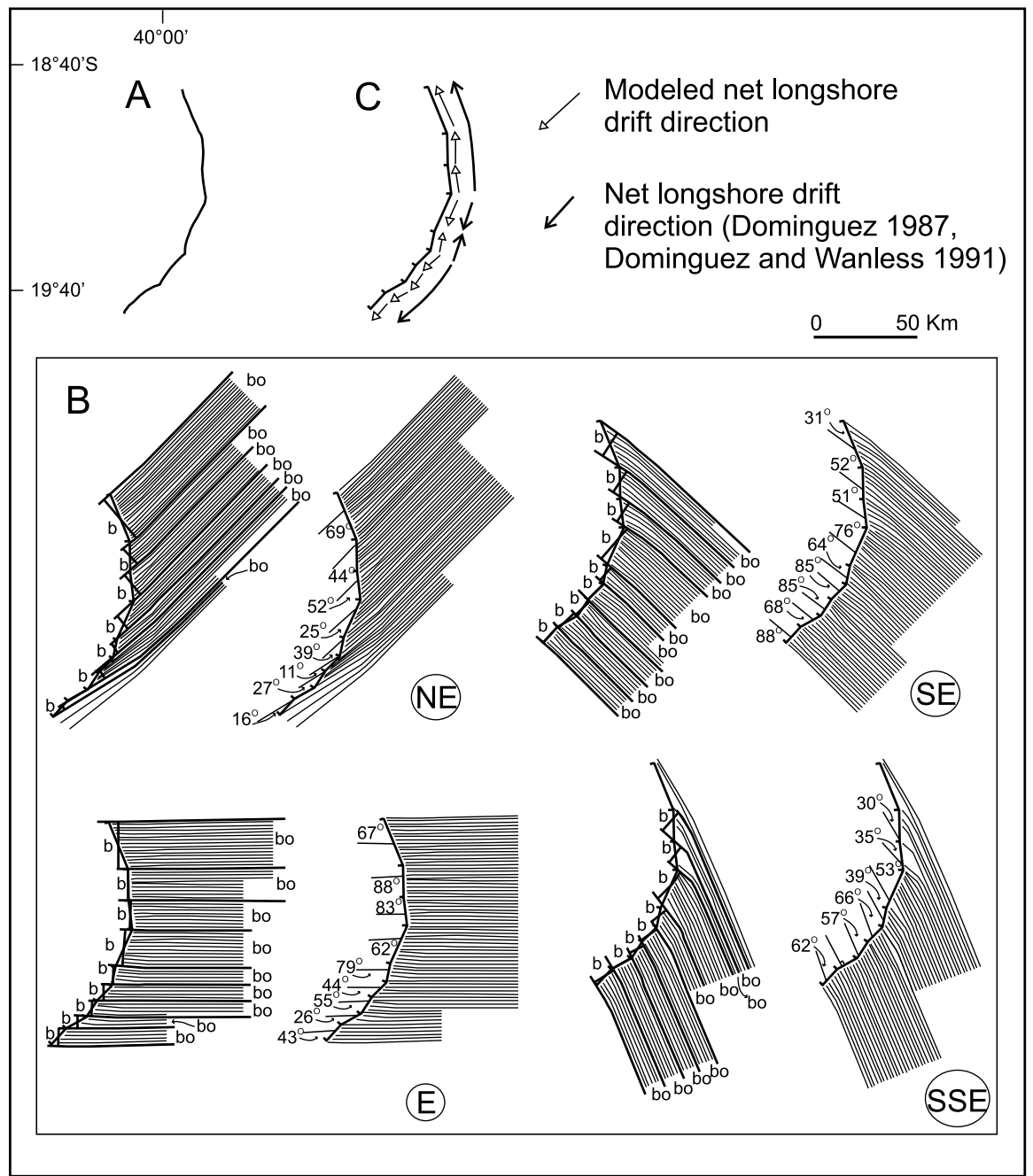

Fig. 6 - (A) Coastline in the Doce River around 3800 cal yr BP (see Fig. 3). (B) Refraction diagrams for waves with a 5-s period, coming from $\mathrm{NE}$ and $\mathrm{E}$, and 6,5-s period, coming from SE and SSE. Here are also shown: 1) different segments into which the shoreline was rectilinearized, 2) incidence angles formed by the wave-rays in relation to the coastal segments and 3) measurements of $b$ and $b_{o}$ (see text) used to estimate wave height along the shore segments. (C) Rectilinearized shoreline showing the directions of net longshore drift of sediments estimated from numerical modeling and from Dominguez (1987) and Dominguez and Wanless (1991).

Palavras-chave: padrões pretéritos e atuais de dispersão de sedimentos, refração de onda, modelagem numérica, Holoceno, Brasil.

\section{REFERENCES}

BACOCCOLI G. 1971. Os deltas marinhos holocênicos brasileiros - Uma tentativa de classificação. Bol Técnico da Petrobrás 14: 5-38.
BASCOM WJ. 1954. The control of stream outlets by wave refraction. J Geol 62: 600-605.

BigARELlA JJ. 1972. Eolian Environments - their characteristics, recognition and importance. In: RIGBY JK AND HAMBLIN WL (Eds), Recognition of Ancient Sedimentary Environments (special issue). SEPM 16: 12-62.

BitTENDOURT ACSP, DOMINGUEZ JML, MARTIN L AND SILVA IR. 2005. Longshore Transport on the Northeastern Brazilian Coast and Implications to the Loca- 
tion of Large Scale Accumulative and Erosive Zones: An Overview. Mar Geol 219: 219-234.

Cerc (Coastal Engineering Research Center). 1984. Shore Protection Manual. U.S. Army Corps of Engineers. Washington, DC, V.I, 597 p.; V. II, 603 p.

DAVIES JL. 1972. Geographical variation in coastal development. Logman Inc New York, 204 p.

DHN (Diretoria de Hidrografia E NAVEgaÇão). 1993. Atlas de Cartas - Piloto. Oceano Atlântico, de Trinidad ao Rio da Prata, $13 \mathrm{p}$.

DOMINGUEZ JML. 1987. Quaternary sea-level changes and the depositional architecture of beach-ridge strandplains along the east coast of Brazil. Ph.D. Thesis, University of Miami, USA, $288 \mathrm{p}$.

DOMINGUEZ JML AND WANLESS HR. 1991. Facies architecture of a falling sea-level strandplain, Doce river coast, Brazil. In: SwIFT DJP AND OERTEL GF (Eds), Shelf Sandstone Bodies (special issue). Int Assoc Sedimentol 14: 259-289.

Dominguez JML, BitTencourt ACSP AND Martin L. 1981. Esquema evolutivo da sedimentação quaternária nas feições deltáicas dos rios São Francisco (SE/AL), Jequitinhonha (BA), Doce (ES) e Paraíba do Sul (RJ). Rev Bras Geocienc 11: 227-237.

Dominguez JML, MARTIN L AND BITTENCOURT ACSP. 1987. Sea-level history and the Quaternary evolution of river mouth-associated beach-ridge plains along the eastsoutheast coast of Brazil: a summary. In: NUMMEDAL D, PILKey DH AND Horward JD (Eds), Sea-Level Fluctuation and Coastal Evolution (special issue). SEPM 41: 115-127.
Dominguez JML, BitTencourt ACSP ANd Martin L. 1992. Controls on Quaternary coastal evolution of the east-northeastern coast of Brazil: roles of sea-level history, trade winds and climate. Sediment Geol 80: 213-232.

Hogben N AND Lumb FE. 1967. Ocean wave statistics. National Physical Lab., Ministry of Technology, London, $263 \mathrm{p}$.

MARTIN L AND SUGUIO K. 1992. Variation of coastal dynamics during the last 7,000 years recorded in beach-ridge plains associated with the central Brazilian coast. Paleo Paleo Paleo 99: 119-140.

Martin L, Suguio K, Dominguez JML And Flexor JM. 1997. Geologia do Quaternário Costeiro do Litoral Norte do Rio de Janeiro e do Espírito Santo. CPRM/Serviço Geológico do Brasil/FAPESP, Belo Horizonte, MG, Brasil, 112 p.

Martin L, Dominguez JML AND BitTencourt ACSP. 1998. Climatic control on coastal erosion during a sealevel fall episode. An Acad Bras Cienc 70: 249-266.

SuguiO K AND MARTIN L. 1981. Significance of Quaternary sea-level fluctuations for delta construction along the Brazilian coast. Geo-Mar Let 3/4: 181-185.

Suguio K AND NogueIRA ACR. 1999. Revisão crítica dos conhecimento geológicos sobre a Formação (ou grupo?) Barreiras do Neógeno e o seu possível significado como testemunho de alguns eventos geológicos mundiais. Geociências 18: 461-479.

Suguio K, Martin L And Dominguez JML. 1982. Evolução do delta do Rio Doce (ES) durante o Quaternário: influência das variações do nível do mar. Atas do IV Simpósio do Quaternário no Brasil, Sociedade Brasileira de Geologia, Rio de Janeiro, RJ, Brasil, p. 93-116. 